\title{
Production Systems Continuous Improvement Modelling
}

\author{
DOI: 510.12776/QIP.V19I2.576 \\ Marina Khayrullina, Olga Kislitsyna, Alexey Chuvaev
}

Received 5 June 2015, Accepted 21 October 2015, Published 31 December 2015

\begin{abstract}
Purpose: This paper focuses on the authors' contribution to modelling algorithms for key business processes, economic indicators and original mathematical model for improvement assessment.

Methodology/Approach: Researching and writing the article one uses interdisciplinary knowledge (technological production processes were considered in unity with economic principles of their construction and management), a combination of technical and technological approach, formal logic and mathematical economic modelling. For justifying the scope of model parameters, it is used field research (enterprises survey) and method of expert evaluation.
\end{abstract}

Findings: The research has showed the integration of theory of constraints, and lean manufacturing is possible and expedient. The observations of the model's integral values and their dynamic patterns allow for important insights about positive or negative trends in production system development taken as a whole. The model enables to reveal the trends for particular items and draw the top teams' attention to problem areas. They will be subject to further decomposing and improvement.

Research Limitation/implication: The model can be treated as cross-functional. But as every enterprise has its unique production environment, it can be exposed to further adjustment to individual enterprise specific conditions.

Originality/Value of paper: The indicators and mathematical model for improvement assessment proposed by authors develop and complement the existing system of knowledge about production management and can be used as a practical tool for control of the continuous improvement process in company.

Category: Research paper

Keywords: continuous improvement; lean production; production system; Theory of Constraints 


\section{INTRODUCTION}

The issues of production management effectiveness have become great concern for academic economists and practical managers. The interest to the subject is enhanced by a growing number of related publications on process management, Lean production, quality management systems, Six-Sigma, etc.

A focus point of many papers is the system of continuous improvement that is based on the Shewhart-Deming concept and Toyota practices extended by other world leading manufacturers. As it follows from the publications, despite a lot of efforts to work out the theory and methodology of effective production management, provide scientific background for novel managerial practices, including those of continuous improvement, many matters are still a remaining academic challenge. Among them is the methodology of company performance assessment that is supposed to help monitor the production system's development and find "working points" for improvement.

\section{KEY THEORETICAL PRINCIPLES AND METHODS}

\subsection{The scope of the concept}

Modern conceptualization of production system is based on Toyota's model (the Toyota Production System), whose backbone is the philosophy of removing waste, finding efficiencies in all production processes and providing safe working conditions. The model involves not only original Toyota's practices but also other methods which have been developed in line with the concept. So, the concept of production systems is associated with such methods and approaches as Lean, Theory of Constraints (TOC), TQM, TPM, JIT (Just-in-Time), Kanban, etc. Their effectiveness depends on how well a company implements Kaizen - a system of continuous improvement which includes consistent measures to maintain and raise performance standards in all processes throughout the production system. This is how the theory can be summarized. In a wider sense, continuous improvements are the systems that allow the produce to conform to the highest world standards, such as Total Quality Control (TQC), Just-in-Time System, Total Productive Maintenance (TPM), Hoshin Kanri - Policy Deployment, Kaizen suggestion system, Small groups' involvement (Gastev, 1972; Zgodavova, Kosc and Kekale, 2001; (Dahlgaard-Park, 2015). These particular systems provide the framework for production systems' development.

The development of new trends in production management over time, emerging concepts and novel managerial tools do not downgrade the importance of the Deming Cycle. Many authors, for example, Imai (1986; 2012), Binner (2010), Womack and Jones (1996), Goldratt (2009) etc. now consider the integration of different implements to raise the effectiveness of management system and provide its continuous improvement. In this article, we look into the integration capability of the basics of Lean Production and the Theory of Constraints. 


\subsection{Methods and procedures}

A methodology framework to translate the concept of continuous improvement into enterprise practices is based on the following:

- system approach to embrace the whole set of interrelated processes within an enterprise considered as an open system with numerous inputs and outputs,

- continuous improvement conception to propel the enterprise to a new level of development at the pivots,

- the conception of production process designed as an unbroken stream.

We assume that any system is subject to some existing or potential constraints that are treated from the perspective of the Theory of Constraints (TOC). To streamline a system and take it from the existing to the targeted development level, TOC and Lean methods have been developed (Table 1). The considerations summarized in the table were touched upon by Dr. Roy Stratton (2012) (CBP\&LL Nottingham Business School NTU Great Britain) in his report at the II International TOCPA Conference (19 - 20 May 2012, Moscow).

Table 1 - TOC and Lean Considerations

\begin{tabular}{|l|l|l|}
\hline \multicolumn{1}{|c|}{ Characteristic } & \multicolumn{1}{|c|}{ TOC approach } & \multicolumn{1}{c|}{ Lean approach } \\
\hline Origin & E. M. Goldratt, 1980-s & T. Ohno (Toyota), 1950-s \\
\hline Process steps & $\begin{array}{l}\text { Step 1. Identify the constraint. } \\
\text { Step 2. Exploit the Constraint. } \\
\text { Step 3. Subordinate and } \\
\text { Synchronize to the Constraint. } \\
\text { Step 4. Elevate Performance of } \\
\text { the Constraint. } \\
\text { Step 5. Repeat the process. }\end{array}$ & $\begin{array}{l}\text { Specify Value } \\
\text { Design a map for value creation } \\
\text { stream. } \\
\text { Value Flow through the Value } \\
\text { Stream. } \\
\text { Pull the Value from the Value } \\
\text { Stream } \\
\text { Strive for Perfection. }\end{array}$ \\
\hline Focus & Managing constraints & Eliminating waste \\
\hline Environment & Complex stream & Naturally stable stream \\
\hline $\begin{array}{l}\text { Methodology } \\
\text { framework }\end{array}$ & $\begin{array}{l}\text { Cause-effect relating / conflict } \\
\text { management }\end{array}$ & Value flow mapping \\
\hline What to be changed & Management rules & Process flow \\
\hline $\begin{array}{l}\text { Key concept/ } \\
\text { improvement tool }\end{array}$ & Buffers control & The Kanban system \\
\hline
\end{tabular}

An idea of integrating The Theory of Constraints with Lean Manufacturing has found its application in many practices gained from field consultants in different industries (Goldratt and Cox, 2009). The approaches described base on the following shared fundamental concepts: 
1) Throughput improvement is considered as the main goal of operations management; Lean - value creation stream; TOC - Buffer Management techniques.

2) Production time indicators and inventory turnover improvement; Lean Just-In-Time System; TOC -Drum - Buffer - Rope method.

3) Management focused on the operational process; Lean - Kanban; TOC Dynamic Buffer Management prioritizing.

It should be noted that unlike pure conceptualizations, practical applications adapt abstractions to a particular environment. An application should rest on some basic assumptions about specified environments. According to Goldratt (2009), for Toyota Production System such an assumption was that of environment stability that emerges in the following three aspects:

- processes and products are not subject to any serious change over a long period,

- steady demand is maintained for every type of products over a long period,

- there is a stable customer-oriented aggregate resources flow.

So when implemented, the approaches generate two key concerns:

- finding qualified tools for variable processes,

- finding the right "working point" and the right time to introduce improvement.

In this article we will focus on the second task. It suggests that a consistent set of indicators should be developed to assess the level of production system's progress and identify bottlenecks that call for management involvement. Before we turn to the indicators, we shall make an outline of enterprise process system.

The modelling procedures for production and business processes to be discussed in this article have the following levels (Figure 1):

- Aggregate Level 1 - general view and key enterprise processes determination,

- Level 2 - production process determination for individual product lines,

- Level 3 - partial operations determination (standardization).

First, we outline the architecture of an enterprise in terms of its mission; determine the range and contents of its flagship "earning" processes, key information and material flows. But corrective work on waist and constraints involves individual operations. So, "bird's eye" view over the enterprise sustainability history is coupled with streamlining (eliminating) some individual processes. 


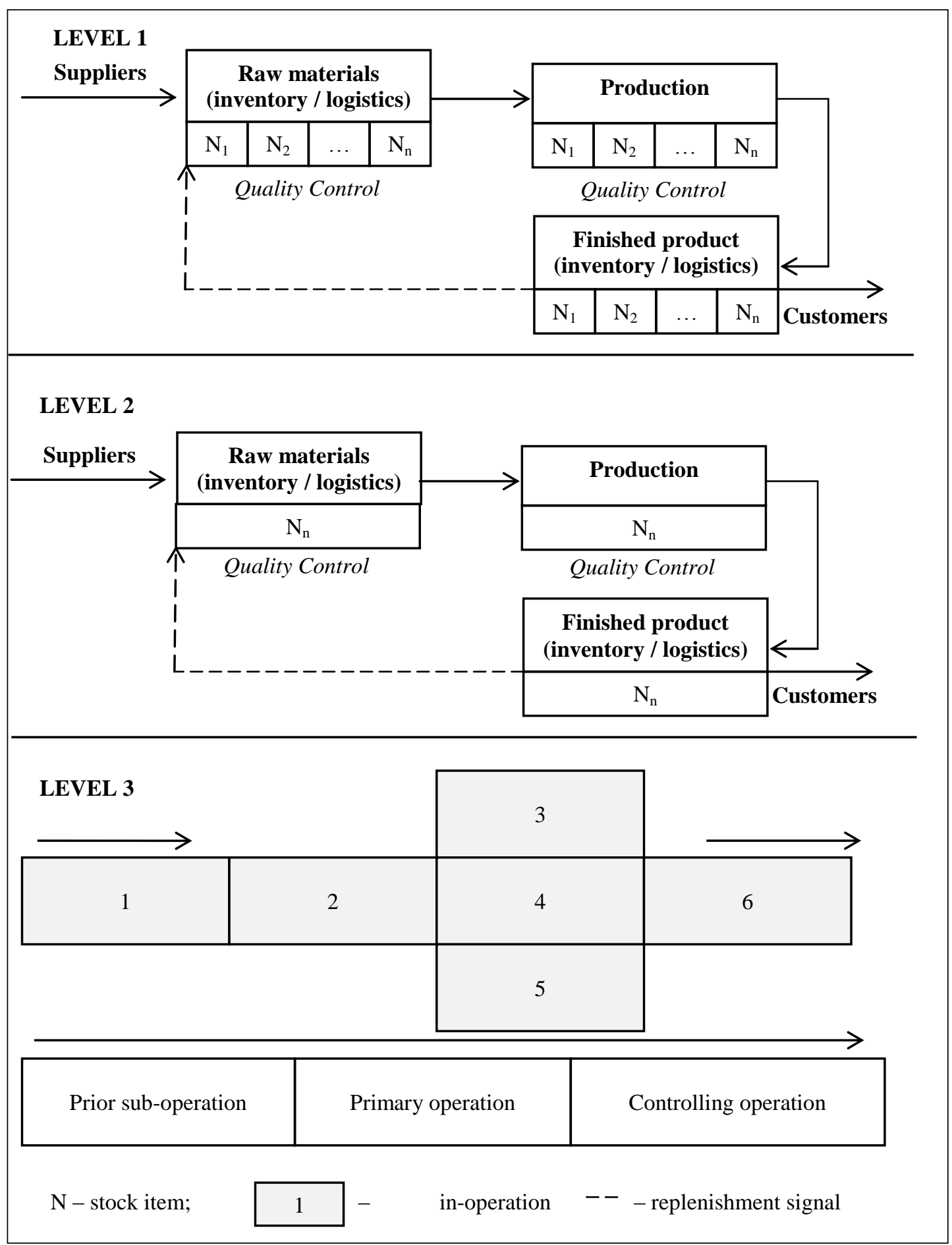

Figure 1-Modelling procedures for production and business processes

The underlying idea of economic and mathematical modelling is as follows. Using the model-calculated integrated value and observations about its change over time, we can estimate continuous improvement trends of an enterprise as a body. Within the model, continuous improvement of individual product lines can be estimated and thus negative trends can be determined to focus top managers' attention on the trouble spots. In this case, we should move to Level 2 and then to 
Level 3 to discern the causes of negative deviations and eliminate the constraint or waste.

A case analysis procedure should consider the process environment type: orderoriented (MTO), availability-oriented (MTA) or their balance. It should also square up material flow types for individual stock items.

Capacity rates are measured against existing and proposed order value over a certain period. The analytical procedures are designed to reveal bottlenecks in process flows at different levels from individual items to the production system at large. The findings will permit to harmonize the jobs of sales and manufacturing departments, work out the rules to launch materials and set priorities in material flows dispatching.

For efficient process modelling at each of the levels the following principles are recommended:

1) For multi-product manufacturing with diverse labour intensity within the product mix, it is a "joint cycle time" principle subject to the system constraints. That is, if the items which differ in labour intensity run through one production cell, their "cycle time" is calculated for the total product line with the resource constraint (time) taken into account.

2) For seasonal production - a production flow flattening principle. It involves components supermarkets, Kanban systems (for continuous flow production with constant product range) and buffer stocks (in any other case). This principle works on sales, inventory and end product turnover.

3) For all production patterns - a synchronized material and information flows principle. An unbroken information field harmonizes individual targets of the parts within the whole system, provides reliable decision support data.

The algorithm summarized in Figure 1 shows outlines of breaking an aggregate production process into individual operations to reveal constraints and improvement areas. A need arises to determine integrated indicators of the level of production system development.

\section{ECONOMIC AND MATHEMATICAL MODELING}

\subsection{Model Indices}

The indices have been selected against the following criteria:

- they refer to the waste to be eliminated within system improvement processes, thus they can be used to estimate upward trends,

- the indices concern key processes which provide the overall system performance as an unbroken consistent flow. 
The model works within the limits of zero investment in capacity expansion.

Selection rationale for model indices:

1) Production Lead Time is one of the most important indicators of Lean Production and the Theory of Constraints. This is an important characteristic for the customer to make choice about the supplier. "If we choose to deal with you, how fast will you carry out our order?" - This is one of the FAQ asked by the customer. Besides, lead-time interval indicates a company's adaptability and its capacity as a system to give immediate response and meet market challenges.

2) Inventory turnover directly identifies one of the key areas of waste described in Lean as "excess inventory". Raw materials, work-in-process, or finished goods in excessive quantities increase production lead time, result in moral aging and product damage, excessive transportation and storage costs, delays and disruptions. Also, waste inventory masks such inefficiencies as unbalanced production, delay in delivery, defects, idle time of equipment and long revamping periods (Liker, 2004; Dettmer and Schragenheim, 2000).

3) Productive capacity indicates the potentialities of an enterprise and its capability to meet the consumer demand to the fullest degree.

4) Production fault rate. Faulty goods production with further elimination of the defects, fixing, revamping, throw-out and returns and replacement generates time waste, idle effort and increases costs.

5) Rates of rejected goods - a very important indicator which many leading companies take into consideration. Unlike manufacturing defects, the defects disclosed by a customer not only lead to cost increase described above, but also undermine the company's image from the customer's perspective, which, in turn, leads to sales slowdown. Negative experience of one customer, passed on by word of mouth, creates negative anticipation among other potential customers.

6) Lost sales opportunities / product or service delays - this indicator is often referred to within the Theory of Constraints framework. Lost sales mean that the company fails to increase its immediate revenue but going forward it may lose its potential customers, while bringing in customers is a challenge that requires a lot of effort and investment.

7) Returns on equity measured against the industry average - an indicator to assess a company's performance against the overall trend and thus to evaluate the validity of improvement strategy implemented. Returns on equity measured for an individual company and taken in isolation is incomplete because the company may be a part of an industry with overall positive trends. Then it can show higher rate even if its management is inconsistent.

8) Material Intensity - this is an important dimension because in manufacturing companies it is material intensity that accounts for $40-$ 
$50 \%$ (for some - up to $80 \%$ ) of their aggregate costs. So, this figures being reduced, an essential increase in performance effectiveness may be achieved.

The model to assess a company's performance using improvement indices described above is presented in Table 2.

To try out the validity of the indices, a survey was conducted. The sample group included manufacturing companies is located in Novosibirsk region. According to the Federal Service for National Statistics, the population of manufacturing companies is 11,967 (January, 1, 2013). Manufacturing activities are defined as activities to transform materials, substances or components into new products by means of chemical and / or physical processing. Their outputs are end products as well as semi-finished products to be exposed to further processing. They fall into 23 groups among which we selected metal fabrication companies (2992) with their percentage in the sectoral structure of Novosibirsk industry being about $25 \%$.

The questionnaires with attached motivating letters were e-mailed to 900 target respondents $(30 \%)$. Data collection period was as long as March - December, 2014. The feedback was 547 returns, among them 156 refused to participate. So, the sample size is 391 .

According to (1), sufficient sample size is as large as (2)

$$
n=\frac{p(1-p) t^{2} N}{e^{2} N+p(1-p) t^{2}}
$$

where $\mathrm{n}$ - necessary sample amount;

$\mathrm{p}$ - sample size variation measured as a proportion; with no prior information input, 0.5 is accepted (peak magnitude);

$\mathrm{t}$-Student's t-test with fixed confidence interval and number of degrees of freedom;

$\mathrm{N}$ - population;

e - acceptable error.

$$
n=\frac{0.5 \cdot(1-0.5) \cdot 1.96^{2} \cdot 2992}{0.05^{2} \cdot 2992+0.5 \cdot(1-0.5) \cdot 1.96^{2}}=340
$$

Thus, the sample size proves statistical significance of the results.

Among the respondents, $17 \%$ were company's chief executives, 59\% production directors, $24 \%$ - heads of production units; $91 \%$ of the respondents had at least 3 years' work experience in executive positions. Thus, those surveyed had considerable expertise and record to return relevant information about their decision-making practices in the field of production system development. 
The companies surveyed produced machinery, electrical equipment and hardware; among them trading companies accounted for approximately $97 \%$ of the total number; the number of employees varied from fewer than $100(63 \%)$ to more than $500(4 \%)$.

Among the 391 respondents, 107 companies showed higher productivity rates against industry average in the last two years. It points to the fact that their executives are efficient and their expertise will make a contribution to this research.

Results assessment procedures involve direct estimation and ranking. This method suggests that in the grading scale the number of points should exceed the number of evaluation criteria by $50-100 \%$. In line with this rule, the respondents were offered to rank the criteria from 1 to 15 ; one rank could not match more than one criterion.

Data processing being completed, significance coefficients were bound to each of the criteria. But the concordance coefficient appeared to reach 0.305, which reveals little concordance among the experts.

In order to better understand the differences between the groups of respondents, the 107 companies were sent follow-up questions asking about their major considerations. Feedback was obtained from 82 companies. Further analysis points out that the differences stem from the companies' focus constraints:

- some companies (29) fail to fulfil customer obligations; their primary concern is lack of equipment or workforce,

- another group (53 respondents) complained about persistent pressure from competitors and difficulties in earning customers' loyalty.

These findings agree completely with the TOC's idea of the two types of constraints:

- capacity constraints,

- market constraints.

As a result, ranking priority indices to evaluate production system development was conducted as a separate procedure for each of the groups. The results are summarized in Table 2. Now the concordance coefficient was 0.691 and 0.753 in the first and second group, respectively. This shows high alignment of the experts. 
Table 2 - Enterprise Performance Assessment Model: Improvement Indices

\begin{tabular}{|c|l|l|c|c|}
\hline № & \multicolumn{1}{|c|}{ Index } & \multicolumn{1}{|c|}{ Units of measure } & $\begin{array}{c}\text { Proportion; } \\
\text { capacity } \\
\text { constraint }\end{array}$ & $\begin{array}{c}\text { Proportion; } \\
\text { market } \\
\text { constraint }\end{array}$ \\
\hline 1 & Production lead time & $\begin{array}{l}\text { seconds, minutes, hours, } \\
\text { days }\end{array}$ & 0.11 & 0.09 \\
\hline 2 & Productive capacity & Equivalent units /time unit & 0.28 & 0.04 \\
\hline 3 & Production fault & Reject frequency rate, \% & 0.15 & 0.07 \\
\hline 4 & $\begin{array}{l}\text { Customer return rates due } \\
\text { to spoilage, } \%\end{array}$ & $\begin{array}{l}\text { Spoilage-caused customer } \\
\text { returns, \% }\end{array}$ & 0.14 & 0.23 \\
\hline 5 & $\begin{array}{l}\text { Inventory turnover } \\
\text { The number of times } \\
\text { inventory is replenished for } \\
\text { a stated period }\end{array}$ & 0.10 & 0.11 \\
\hline 6 & $\begin{array}{l}\text { Lost sales/ delayed goods } \\
\text { or services }\end{array}$ & $\begin{array}{l}\text { \% (measured against } \\
\text { revenue) }\end{array}$ & 0.05 & 0.31 \\
\hline 7 & $\begin{array}{l}\text { Returns on equity (ROE) } \\
\text { against ROE within the } \\
\text { industry }\end{array}$ & $\begin{array}{l}\text { Excess of an enterprise's } \\
\text { ROE over ROE within the } \\
\text { industry, \% }\end{array}$ & 0.11 & 0.10 \\
\hline 8 & Materials intensity & $\begin{array}{l}\text { Equivalent units of } \\
\text { materials/ Standard units of } \\
\text { product (service) }\end{array}$ & 0.06 & 0.05 \\
\hline TOTAL & \multicolumn{2}{|l}{1.00} & 1.00 \\
\hline
\end{tabular}

\subsection{First level integrated indices modelling}

A set of indicators to estimate enterprise performance in accordance with Lean and TOC principles is given by a multitude:

$$
F=\left\{F_{1}, \ldots, F_{n}\right\}
$$

where $1, \ldots, \mathrm{n}$ - ordinal notation of an indicator.

A set of the above indicators' absolute values takes the form:

$$
F^{a}=\left\{F_{1}^{a}, \ldots, F_{n}^{a}\right\}
$$

Then a set of relative value changes of the indicators is as follows:

$$
\Delta F^{a}=\left\{\Delta F_{1}^{a}, \ldots, \Delta F_{n}^{a}\right\}
$$

According to its relative value change, every index is assigned a coefficient to estimate improvement. For Indices 1 and 8 (Table 2), improvement coefficient is assigned with the following formula: 


$$
\left\{\begin{array}{l}
\text { If } \Delta F_{i}^{a} \leq-5 \% \Rightarrow k_{i}=1 \\
\text { If }-5 \%<\Delta F_{i}^{a}<5 \% \Rightarrow k_{i}=-\frac{\Delta F_{i}^{a}}{5 \%} \\
\text { If } \Delta F_{i}^{a}>5 \% \Rightarrow k_{i}=-1
\end{array}\right.
$$

For Indices 2, 5, 7 (Table 2), the coefficient is assigned with the following formula:

$$
\left\{\begin{array}{l}
\text { If } \Delta F_{i}^{a} \leq-5 \% \Rightarrow k_{i}=-1 \\
\text { If }-5 \%<\Delta F_{i}^{a}<5 \% \Rightarrow k_{i}=\frac{\Delta F_{i}^{a}}{5 \%} \\
\text { If } \Delta F_{i}^{a}>5 \% \Rightarrow k_{i}=1
\end{array}\right.
$$

For Indicators 3, 4, 6 (Table 2), the coefficient is assigned with the following formula:

$$
\left\{\begin{aligned}
& \text { If } F_{i}^{a}=0 \Rightarrow k_{i}=1 \\
& \text { If } F_{i}^{a} \neq 0 \Rightarrow\left\{\begin{array}{l}
\text { If } F_{i}^{a} \text { priorperiol } \\
\text { If } \Delta F_{i}^{a} \leq-5 \% \Rightarrow k_{i}=1 \\
\text { If }-5 \%<\Delta F_{i}^{a}<5 \% \Rightarrow k_{i}=-\frac{\Delta F_{i}^{a}}{5 \%} \\
\text { If } \Delta F_{i}^{a}>5 \% \Rightarrow k_{i}=-1
\end{array}\right.
\end{aligned}\right.
$$

This way a complete set of coefficients is formed for the whole set of indices listed in Table 2:

$$
K=\left\{k_{1}, \ldots, k_{n}\right\}
$$

Next, a performance analysis was held in a number of enterprises, its results being then submitted to expert evaluation. By the expertise ratios scale was created to estimate a relative weight of every indicator:

$$
W=\left\{w_{1}, \ldots, w_{n}\right\}
$$

Note that the indicators vary in the order of priority with a constraint type (capacity-caused or market-caused constraints). The ratios suggested are deduced from the results of particular manufacturing enterprises. But they are adaptable to individual circumstances, environment and specific goals set by the top management of any business. 
Integrated evaluation of enterprise performance can be found with the following formula:

$$
K_{I}=\sum_{i=1}^{n} K_{i} w_{i}
$$

If an enterprise's product/service range is excessively diverse, the indices and their integrated value should be calculated for all the product lines.

The importance (ratio) of a product line is measured against one of the following criteria:

- sales revenue,

- labour intensity,

- variable production costs.

Then:

$$
K_{I}=\sum_{J=1}^{m} K_{I}^{j} d_{j}
$$

where $\mathrm{Ki}$ - integrated estimate of an enterprise taken in aggregate;

$\mathrm{K}_{\mathrm{J}}^{\mathrm{I}}$ - integrated estimate of $\mathrm{j}$-product line;

$\mathrm{d}_{\mathrm{j}}-\mathrm{j}$-product line ratio;

$\mathrm{m}-$ number of product lines to be estimated

Given the integrated index is obtained; we can measure the production system development by grading it as follows (Table 3 ):

Table 3 - Integral values grading scale

\begin{tabular}{|c|c|}
\hline Development level & Integral estimate \\
\hline High & {$[0.67 ; 1]$} \\
\hline Average & {$[0.33 ; 0.67)$} \\
\hline Low & {$[0 ; 0.33)$} \\
\hline Negative & {$[-1 ; 0)$} \\
\hline
\end{tabular}

If the value falls below zero, this is a signal of adverse trends; the company's market power is challenged, it is running into severe problems. The executives should look closely at the production system and find "working points" for improvements.

The positive magnitude range, for the sake of simplicity and convenient practical application, was divided into three zones, which is in a similar way to TOC:

- $[0 ; 0.33)$ - "red zone": the system shows low efficiency and "overcooling" development, as a consequence, its present market position may be dented in the nearest future. This is a message to the executives that many aspects need work,

- $[0.33 ; 0.67)$ - "yellow zone" indicates an average level of efficiency; most indicators show upward trend, the company is doing quite well, 
- $[0.67 ; 1]$ - "green zone": a high level of efficiency; the enterprise is developing in the right direction and its management have strong commitment to permanently refine all processes. This definitely leads to higher competitiveness and consolidated market position.

\section{CONCLUSION}

The research has shown that suggested implementation of integrated TOC and Lean tools and methods is a reasonable and promising idea. To provide the integration, a set of indicators has been developed. The indicators are targeted at reducing production time and waste; maximizing customer satisfaction with the quality and delivery time; increasing the returns on equity. The model suggests a few assumptions, as it has been designed as a universal pattern with shared underlying principles, procedures and criteria. For an individual enterprise or manufacturing environment the model can be further adapted in terms of the indicators' composition and ratios.

The integral values grading scale enables to evaluate production system, its present level and trends of development and thus identify actual areas that need work (operation management, quality control, investment management); focus on the troubled processes then break them into individual operations and items to reveal constraints and bottlenecks within the system.

Discussed in the article are the results of only one stage of a broader investigation. As we go further, we plan to work out a methodology of selecting benchmarks for high-tech business processes, optimization models for business processes, multi-flow models, decision-making patterns in manufacturing, risk evaluation and mitigation methodology for innovative companies. The results will advance our knowledge of important economic and management phenomena and processes in the field of modern manufacturing.

\section{REFERENCES}

Binner, H., 2010. Organizations and Production Management. From functional to process management. Moscow: Alpina Publishers.

Cox, J., Jacob, D. and Bergland, S., 2009. Velocity: Combining Lean, Six Sigma and the Theory of Constraints to Achieve Breakthrough Performance - A Business Novel. New York: Free Press.

Dahlgaard-Park, S. ed., 2015. The sage encyclopedia of quality and the service economy. (Vols. 1-2). Thousand Oaks, CA: SAGE Publications, Inc. DOI: $10.4135 / 9781483346366$.

Dettmer, W. and Schragenheim, E., 2000. Manufacturing at Warp Speed: Optimizing Supply Chain Financial Performance. Boca Raton: St. Lucie Press.

Gastev, A.K., 1972. Kak nado rabotat'. Leningrad: Pecahtniy dvor. 
Goldratt, E. and Cox, J., 2009. The Goal: A Process of Ongoing Improvement. New York: North River Press.

Goldratt, E.M., 2009. Standing on the Shoulders of Giants - Production concepts versus production applications The Hitachi Tool Engineering example. Gestão \& Produção, 16 (3), pp.333-343.

Imai, M., 1986. Kaizen: The Key to Japan's Competitive Success. Moscow: Alpina Publishers. New York: McGraw-Hill.

Imai, M., 2012. Gemba Kaizen: A Commonsense Approach to a Continuous Improvement Strategy. $2^{\text {nd }}$ ed. New York: McGraw Hill Education.

Liker, J., 2004. The Toyota Way: 14 Management Principles from the World's Greatest Manufacturer. New York: McGraw-Hill Education.

Stratton, R., 2012. TOC, Lean manufacturing and 6 sigma. In: $2^{\text {nd }}$ International TOCPA Conference. Moscow, Russian Federation, 19-20 May 2012. Available at: http://www.tocpractice.com/ru/page/d-r-roi-stratton-dr-roy-stratton-tosberezhlivoe-proizvodstvo-i-6-sigma\#tattachments [Accessed 30 March 2015].

Womack, J.P. and Jones, D.T., 1996. Lean Thinking: Banish Waste and Create Wealth in Your Corporation. New York: Free Press.

Young, R.M., 2001. Production Systems in Cognitive Psychology. In: N.J. Smelser and P.B. Baltes, eds. 2001. International Encyclopedia of the Social \& Behavioral Sciences. pp.12143-12146. Available at:

http://citeseerx.ist.psu.edu/viewdoc/download?doi=10.1.1.12.9158\&rep=rep1\&ty pe=pdf [Accessed 04 August 2014].

Zgodavova, K., Kosc, P., Kekale, T., 2001. Learning before doing: utilising a co-operative role play for quality management in a virtual organisation. Journal of Workplace Learning, 13(3), pp.113-119, DOI: 10.1108/13665620110388415.

\section{ABOUT AUTHORS}

Prof. Marina Khayrullina, D.Sc., Dean of the Faculty of Business, Novosibirsk State Technical University, K. Marx, 20, Novosibirsk, Russian Federation. e-mail: khayrullina@corp.nstu.ru

Doc. Olga Kislitsyna, PhD, Management Department, Faculty of Business, Novosibirsk State Technical University, K. Marx, 20, Novosibirsk, Russian Federation. e-mail: kislicyna@ corp.nstu.ru

Alexey Chuvaev, M.Sc., Assistant Professor, Management Department, Faculty of Business, Novosibirsk State Technical University, K. Marx, 20, Novosibirsk, Russian Federation. e-mail: achuvaev@inbox.ru 